\title{
ANALISIS INTERFERENSI GRAMATIKAL DALAM TEKS BIOGRAFI SISWA
}

\author{
Ayu Puspita Indah Sari ${ }^{1}$, Midra Azrianti Harahap ${ }^{2}$ \\ Dosen Universitas Bina Darma ${ }^{1}$, Mahasiswa Universitas Bina Darma ${ }^{2}$ \\ Jalan Jenderal Ahmad Yani No.3 Palembang
}

Sur-el: ayupuspita.indahsari@binadarma.ac.id ${ }^{1}$, midraazrianti@ gmail.com²

Article info

Article history:

Received: 08-04-2019

Revised : 15-04-2019

Accepted: 15-06-2019

\begin{abstract}
A B S T R A C T
This research is motivated by the use of language in students' biographical texts. The problem in this research is how the form of grammatical interference in Indonesian language in the biographical text of class X students of SMA Negeri 1 Palembang and what factors are the causes of the grammatical interference of Indonesian in the biography of students. The results of this study indicate that the form of Indonesian grammatical interference in the biographical text of students in the level of morphology includes affixation, reduplication, and composition. In affixation, there is a form of interference with one word prefix, prefix 4 words, 1 word prefix, suffix + suffix 1 word, confix 4 words, confirm + suffix 1 word, confixing 1 word, confirming 1 word, clophyte 1 word, and clophyte in one word, while the reduplication and composition process is not found in the biographical text of the student. Factors that cause the occurrence of grammatical interference are the participant's bilingualism, the thinness of the recipient's language loyalty, and the practice of habits in the mother language.
\end{abstract}

Keywords: grammatical interference, Indonesian language, biography text

Kata Kunci: interferensi gramatikal,bahasa Indonesia,teks biografi
Penelitian ini dilatarbelakangi oleh penggunaan bahasa dalam teks biografi siswa. Permasalahan dalam penelitian ini adalah bagaimana bentuk interferensi gramatikal bahasa Indonesia dalam teks biografi siswa kelas X SMA Negeri 1 Palembang dan faktor apa saja yang menjadi penyebab terjadinya interferensi gramatikal bahasa Indonesia dalam teks biografi siswa. Hasil penelitian ini menunjukkan bahwa bentuk interferensi gramatikal bahasa Indonesia dalam teks biografi siswa tataran morfologi meliputi afiksasi, reduplikasi, dan komposisi. Pada afiksasi, terdapat bentuk interferensi prefiks ber- 1 kata, prefiks me- 4 kata, prefiks pe- 1 kata, sufiks-an + sufiks-nya 1 kata, konfiks di4 kata, konfiks ke-an + sufiks-nya 1 kata, konfiks pe-an 1 kata, konfiks ke-an 1 kata, klofiks me-i 1 kata, dan klofiks di- 1 kata, sedangkan proses reduplikasi dan komposisi tidak ditemukan dalam teks biografi siswa. Faktor yang menyebabkan terjadinya interferensi gramatikal yaitu kedwibahasawan peserta tutur, tipisnya kesetiaan pemakai bahasa penerima, dan terbawanya kebiasaan dalam bahasa Ibu. 


\section{JURNAL ILMIAH \\ BINA EDUKASI \\ ISSN 1979-8598 E-ISSN: 2655-8378 \\ http://journal.binadarma.ac.id/index.php/jurnalbinaedukasi \\ Vol. 12, No. 1, Juni 2019, 57 - 71}

\section{PENDAHULUAN}

Bahasa merupakan alat yang digunakan untuk berinteraksi atau berkomunikasi baik secara lisan maupun tulisan. Tanpa bahasa, seseorang tidak dapat berinteraksi antarsesama. Tidak hanya kecakapan dalam berbicara saja, seseorang harus terampil juga dalam berkomunikasi melalui sebuah tulisan. Karena sebuah tulisan merupakan bentuk komunikasi antarpenulis dan pembaca, melalui sebuah tulisan tersebut berfungsi untuk menyampaikan informasi kepada pembacanya. Penulis harus menggunakan bahasa yang baik dalam tulisannya agar informasi yang disampaikan melalui tulisan itu dapat dimengerti oleh pembaca. Sebaliknya, jika bahasa yang digunakan kurang baik dalam sebuah tulisan, maka informasi yang diharapkan pembaca dalam sebuah tulisan tidak akan tercapai.

Penelitian tentang interferensi pernah dilakukan oleh Putri (2014) dengan judul "Interferensi Leksikal Bahasa Indonesia dalam Bahasa Jawa pada Karangan Narasi Siswa Kelas VII SMP Negeri 1 Bukateja di Kabupaten Purbalingga", Putri menyimpulkan bahwa terdapat interferensi leksikal berupa kata pinjaman, adapun faktor penyebab interferensi dibagi menjadi lima yaitu: (a) kedwibahasawan siswa; (b) kebiasaan siswa menggunakan bahasa Indonesia; (c) bahasa pengantar pembelajaran bahasa Jawa lebih sering menggunkan bahasa Indonesia; (d) pemahaman kata-kata dalam bahasa Jawa rendah; dan (e) keterbatasan kosakata.

Interferensi sering terjadi di lingkungan sekitar, salah satunya di lingkungan sekolah seperti di jenjang Sekolah Menengah Atas (SMA). Interferensi dapat terjadi dalam bahasa lisan maupun tulis siswa. Berdasarkan hasil observasi pada tanggal 5 September 2017 yang telah dilakukan terhadap tulisan siswa kelas X SMA Negeri 1 Palembang, penulis melihat banyak sekali terdapat interferensi gramatikal dalam tulisan siswa, salah satunya di lembar jawaban ulangan harian siswa mengenai materi teks anekdot. Sebagai contoh: "Kalau dia tegak nanti kursinya didudukin orang lain", pada kalimat tersebut terjadi interferensi gramatikal dalam tataran morfologi pada pembentukan kata dasar (afiksasi) yaitu kata "didudukin" yang seharusnya ditulis "diduduki".

Interferensi dalam bidang gramatikal meliputi interferensi yang terjadi pada bidang morfologi dan sintaksis. Tetapi, pada penelitian ini hanya akan meneliti interferensi gramatikal yang terjadi pada bidang interferensi morfologi. Interferensi morfologi yang diteliti meliputi proses pembentukan kata pada bagian afiksasi, reduplikasi, dan komposisi (pemajemukan).

Adapun rumusan masalah dalam penelitian ini adalah (1) bagaimanakah bentuk interferensi gramatikal bahasa Indonesia dalam teks biografi siswa kelas X SMA Negeri 1 Palembang? dan (2) faktor apa saja yang menjadi penyebab terjadinya interferensi gramatikal bahasa Indonesia dalam teks biografi siswa kelas X SMA Negeri 1 Palembang?, sedangkan tujuan dari penelitian ini adalah (1) untuk mendeskripsikan interferensi gramatikal bahasa 
Indonesia dalam teks biografi siswa kelas X SMA Negeri 1 Palembang; dan (2) untuk mendeskripsikan faktor penyebab terjadinya interferensi gramatikal bahasa Indonesia dalam teks biografi siswa kelas X SMA Negeri 1 Palembang.

\section{METODOLOGI PENELITIAN}

\subsection{Interferensi}

Istilah interferensi pertama kali digunakan oleh Weinreich dalam Chaer dan Agustina (2010: 120) menyatakan bahwa "untuk menyebut adanya perubahan sistem suatu bahasa sehubungan dengan adanya persentuhan bahasa tersebut dengan unsur-unsur bahasa lain yang dilakukan oleh penutur bilingual".

Chaer dan Agustina (2010: 120) menyatakan bahwa "peristiwa interferensi juga digunakannya unsur-unsur bahasa lain dalam menggunakan suatu bahasa, yang dianggap sebagai suatu kesalahan karena menyimpang dari kaidah atau aturan bahasa yang digunakan. Penyebab terjadinya interferensi ini adalah terpulang pada kemampuan si penutur dalam menggunakan bahasa tertentu sehingga dia dipengaruhi oleh bahasa lain. Biasanya interferensi ini terjadi dalam menggunakan bahasa kedua (B2), dan yang berinterferensi ke dalam B2 itu adalah B1 atau bahasa ibu".

\subsubsection{Jenis-jenis Interferensi}

Interferensi merupakan gejala umum dalam sisiolinguistik yang terjadi sebagai akibat dari kontak bahasa, yaitu penggunaan dua bahasa atau lebih dalam masyarakat tutur yang multilingual. Hal ini merupakan suatu masalah yang menarik perhatian para ahli bahasa. Mereka memberikan pengamatan dari sudut pandang yang berbeda-beda. Dari pengamatan para ahli tersebut timbul bermacam-macam interferensi.

Weinreich dalam Aslinda dan Syafyahya (2014: 67) juga membagi bentuk-bentuk interferensi atas tiga bagian, yaitu interferensi fonologi, interferensi leksikal, dan interferensi gramatikal. Lebih rinci akan dijelaskan sebagai berikut.

a. Interferensi dalam bidang fonologi

Bila kita rujuk kembali pendapat Weinreich yang menyebutkan adanya interferensi dalam bidang bunyi, ternyata dalam interferensi bahasa Minang Kabau terhadap bahasa Indonesia ditemukan interferensi dalam bidang fonem, dan dalam bidang bunyi atau fonetik. Akan tetapi, tampaknya interferensi dalam bidang fonetik terbatas pada beberapa orang saja dan tidak bersifat umum.

b. Interferensi dalam bidang leksikal

Interferensi dalam bidang leksikal terjadi apabila seorang dwibahasawan dalam peristiwa tutur memasukkan leksikal bahasa pertama ke dalam bahasa kedua atau 


\section{JURNAL ILMIAH \\ BINA EDUKASI \\ ISSN 1979-8598 E-ISSN: 2655-8378 \\ http://journal.binadarma.ac.id/index.php/jurnalbinaedukasi \\ Vol. 12, No. 1, Juni 2019, 57 - 71}

sebaliknya. Dalam hal interferensi leksikal, kami menganalisisnya berdasarkan pembagian kelas kata. Setelah mengklasifikasikan data, kami hanya menemukan lima kelas kata yang mengalami interferensi leksikal, yaitu kelas verba, kelas adjektiva, kelas nomina, kelas pronomina, dan kelas kata numeralia.

c. Interferensi dalam bidang gramatikal

Interferensi dalam bidang gramatikal terjadi apabila dwibahasawan mengidentifikasi morfem, kelas morfem, atau hubungan ketatabahasaan pada sistem bahasa pertama dan menggunakannya dalam tuturan bahasa kedua, dan demikian sebaliknya. Sesuai dengan pendapat Weinreich dalam Aslinda dan Syafyahya (2014: 74), bahwa gejala interferensi itu berupa fonik, gramatikal (morfologi dan sintaksis), dan leksikal. Jadi interferensi yang terjadi pada bidang morfologi dan sintaksis dimasukkan ke dalam bidang gramatikal.

1) Interferensi Morfologi

Interferensi dalam bidang morfologi dapat terjadi antara lain pada penggunaan unsur-unsur pembentukan kata, pola proses morfologi, dan proses penanggalan afiks (Aslinda dan Syafyahya, 2014: 75).

2) Interferensi Sintaksis

Interferensi bidang sintaksis antara lain meliputi penggunaan kata tugas bahasa pertama pada bahasa kedua atau sebaliknya, pada pola konstruksi frase.

\subsubsection{Faktor-Faktor yang Menyebabkan terjadinya Interferensi}

Weinrich dalam Suandi, (2014: 117) mengatakan bahwa ada beberapa faktor yang menyebabkan terjadinya interferensi, antara lain:

1. Kedwibahasaan peserta tutur;

2. Tipisnya kesetiaan pemakai bahasa penerima;

3. Tidak cukupnya kosakata bahasa penerima;

4. Menghilangnya kata-kata yang jarang digunakan;

5. Kebutuhan akan sinonim;

6. Pretise bahasa sumber dan gaya bahasa;

7. Terbawanya kebiasaan dalam bahasa ibu

\subsubsection{Biografi}

Biografi berasal bahasa Yunani, yaitu dari kata bios yang berarti hidup, dan graphien yang berarti tulis. Teks biografi merupakan teks riwayat hidup seseorang atau tokoh yang ditulis oleh orang lain. Akan tetapi, jika riwayat hidup seseorang ditulis sendiri oleh orang tersebut, hasilnya disebut autobiografi (Kemendikbud dalam Mulya, 2017: 44).

Biografi memuat identitas dan peristiwa yang dialami seseorang, termasuk karya dan penghargaan yang diterima dan permasalahan yang dihadapinya. Uraian tentang identitas berisi 


\section{JURNAL ILMIAH \\ BINA EDUKASI \\ ISSN 1979-8598 E-ISSN: 2655-8378 \\ http://journal.binadarma.ac.id/index.php/jurnalbinaedukasi \\ Vol. 12, No. 1, Juni 2019, 57 - 71}

antara lain nama, tempat dan tanggal lahir, latar belakangkeluarga, riwayat pendidikan, dan riwayat organisasi yang diikuti.Uraian tentang peristiwa berisi kejadian yang dialami tokoh dalam mengharumkanbangsa, mengembangkan karier, atau hambatan, tantangan, atau kendala yang dihadapi tokoh dalam mencapai tujuan dan cita-citanya.

\subsubsection{Metode Penelitian}

Arikunto (2015: 203) menyatakan bahwa metode penelitian adalah cara yang digunakan oleh peneliti dalam mengumpulkan data penelitiannya. Metode penelitian mencakup bahan atau materi penelitian, alat, jalan penelitian, variabel, dan data yang hendak disediakan dan analisis data (Mahsun, 2006: 70). Metode yang digunakan dalam penelitian ini adalah metode deskriptif. "Metode deskriptif merupakan metode penelitian yang berusaha menggambarkan dan menginterpretasikan objek sesuai dengan apa adanya" (Sukardi, 2014: 157).

\subsubsection{Tempat dan Waktu Penelitian}

Penelitian ini dilaksanakan di SMA Negeri 1 Palembang, yang beralamat di Jalan Srijaya Negara Nomor 10 Kecamatan Ilir Barat 1 Kelurahan Bukit Lama Palembang 30139 Telepon (0711) 351127. Adapun waktu penelitian ini dilaksanakan pada semester genap tahun ajaran 2017/2018.

\subsubsection{Populasi dan Sampel Penelitian}

Populasi dalam penelitian ini adalah siswa kelas X SMA Negeri 1 Palembang yang berjumlah 476 orang siswa. Sementara,teknik dalam pengambilan sampel pada penelitian ini adalah dengan menggunakan sampel bertujuan atau purposive sample. Sampel bertujuan dilakukan dengan cara mengambil subjek bukan didasarkan atas strata, random atau daerah tetapi didasarkan atas adanya tujuan tertentu (Arikunto, 2015: 183).Penelitian ini dilakukan terhadap siswa kelas X SMA Negeri 1 Palembang. Sementara kelas X di SMA Negeri 1 Palembang ini sebanyak 14 kelas, yang terdiri dari 9 kelas IPA dan 5 kelas IPS.Sebanyak 14 kelas yang ada di kelas X, peneliti mengambil kelas X IPA 4 sebagai sampel penelitian. hal ini dikarenakan pada saat peneliti melakukan observasi tehadap kelas X, peneliti menemukan interferensi gramatikal yang paling banyak terdapat pada tulisan siswa kelas X IPA 4 tersebut yang terdiri dari 36 siswa.

\subsubsection{Teknik Pengumpulan Data}

Teknik pengumpulan data yang digunakan dalam penelitian ini sebagai berikut.

1. Dokumentasi

Metode dokumentasi yang digunakan dalam penelitian ini adalah berupa tulisan siswa yaitu teks biografi. Arikunto (2015: 274) menyatakan bahwa "Metode dokumentasi, yaitu mencari data mengenai hal-hal atau variabel yang berupa catatan, transkrip, buku, surat kabar, majalah, prasasti, notulen rapat, lengger, agenda, dan sebagainya. 


\section{JURNAL ILMIAH \\ BINA EDUKASI \\ ISSN 1979-8598 E-ISSN: 2655-8378 \\ http://journal.binadarma.ac.id/index.php/jurnalbinaedukasi \\ Vol. 12, No. 1, Juni 2019, 57 - 71}

\section{Angket/kuesioner}

Kuesioner adalah sejumlah pertanyaan tertulis yang digunakan untuk memperoleh informasi dari responden dalam arti laporan tentang pribadinya, atau hal-hal yang ia ketahui (Arikunto, 2015: 194). Angket atau kuesioner yang digunakan dalam penelitian ini adalah jenis kuesioner isian. Kuesioner isian yang dimaksud sama dengan kuesioner terbuka.Arikunto (2015: 195) menjelaskan bahwa kuesioner terbuka adalah kuesioner yang memberi kesempatan kepada responden untuk menjawab dengan kalimatnya sendiri. Senada dengan pendapat Sugiyono (2017: 200) yang menyatakan bahwa pertanyaan terbuka adalah pertanyaan yang mengharapkan responden untuk menuliskan jawabannya berbentuk uraian tentang suatu hal.

Angket atau kuesioner yang digunakan dalam penelitian ini adalah untuk mengetahui faktor penyebab interferensi gramatikal pada teks biografi yang ditulis siswa. Angket penelitian ini sudah diujikan melalui uji bahasa oleh ahli bahasa yaitu salah satu dosen pendidikan bahasa Indonesia Universitas Bina Darma.

\subsubsection{Teknik Analisis Data}

Teknik analisis data yang digunakan dalam penelitian ini adalah teknik padan intralingual. "Teknik padan intralingual adalah metode analisis dengan cara menghubung atau membandingkan unsur-unsur yang bersifat lingual, baik yang terdapat dalam satu bahasa maupun dalam beberapa bahasa yang berbeda" (Mahsun, 2007: 117). Peneliti menggunakan teknik ini untuk mengetahui interferensi gramatikal bahasa Indonesia dalam teks biogafi siswa.

\subsubsection{Teknik Penyajian Data}

Penyajian hasil analisis data dalam penelitian ini menggunakan metode informal. "Metode informal yaitu berupa rumusan dengan menggunakan kata-kata biasa, termasuk penggunaan terminologi yang bersifat teknis" (Mahsun, 2007: 123). Penggunaan metode informal dalam penyajian hasil analisis data karena penelitian ini bersifat deskriptif. Pendeskripsian dari gejala atau keadaan yang terjadi pada objek penelitian. Data berupa dokumentasi yaitu teks biografi yang ditulis siswa yang mengalami interferensi diungkapkan secara apa adanya berdasarkan data yang ada, sehingga hasil penelitian ini benar-benar merupakan suatu fenomena bahasa yang sesungguhnya. Data yang sudah dianalisis kemudian diberi penjelasan di bawahnya mengenai jenis interferensi, analisis dan sumber data. Sedangkan data angket dideskripsikan berdasarkan persentase yang telah dianalisis sebelumnya, kemudian disajikan dalam bentuk gambar berupa grafik batang untuk menunjukkan tingkat faktor penyebab terjadinya interferensi. 


\section{JURNAL ILMIAH \\ BINA EDUKASI \\ ISSN 1979-8598 E-ISSN: 2655-8378 \\ http://journal.binadarma.ac.id/index.php/jurnalbinaedukasi \\ Vol. 12, No. 1, Juni 2019, 57 - 71}

\section{HASIL DAN PEMBAHASAN}

\subsection{Hasil Penelitian}

Bentuk-bentuk interferensi gramatikal bahasa Indonesia dalam teks biografi siswa kelas X SMA Negeri 1 Palembang terlihat lebih mudah jika dideskripsikan. Interferensi gramatikal yang dibahas dalam penelitian ini hanya berfokus pada interferesi pada tataran morfologi. Berikut adalah hasil deskripsi data terhadap sampel penelitian sebanyak tiga puluh enam 36 siswa pada teks biografi siswa.

\subsubsection{Bentuk Interferensi Gramatikal}

Dapat dideskripsikan bahwa interferensi gramatikal pada tataran morfologi meliputi afiksasi, reduplikasi dan komposisi. Dalam bentuk afiksasi terdapat interferensi yaitu pada prefiks ber- terdapat 1 kata yaitu pada data 3, data 10, dan data 35. Prefiks me- terdapat 4 kata yaitu pada data 9, data 32 , data 34 , dan data 35 , Prefiks pe- terdapat 1 kata yaitu pada data 35. Sufiks - an + sufiks - nya terdapat 1 kata yaitu pada data 32. Konfiks di-i terdapat 4 kata yaitu pada data 7 , data 11 , data 12 , dan data 35 . Konfiks ke-an + sufiks -nya terdapat 1 kata yaitu pada data 3. Konfiks pe-an terdapat 1 kata yaitu pada data 14. Konfiks ke-an terdapat 1 kata yaitu pada data 11 . Klofiks me-ii terdapat 1 kata yaitu pada data 11, dan pada klofiks di-kan terdapat 1 kata yaitu pada data 35. Sedangkan bentuk reduplikasi dan komposisi tidak ditemukan dalam teks biografi yang ditulis siswa.

\subsubsection{Faktor-Faktor yang Menyebabkan terjadinya Interferensi}

Berdasarkan hasil angket penelitian terhadap tiga puluh enam (36) sampel, peneliti melakukan perhitungan setiap pertanyaan angket yang telah diisi siswa, peneliti menemukan bahwa, ada tiga faktor yang menjadi penyebab terjadinya interferensi pada teks biografi siswa, sebagai berikut.

a. Kedwibahasaan peserta tutur.

Kedwibahasaan peserta tutur terlihat dari pertanyaan angket nomor 1 dan 12, sehingga dirata-ratakan sebanyak 98,61\% siswa yang dwibahasawan.

b. Tipisnya kesetiaan pemakai bahasa penerima.

Tipisnya kesetiaan pemakai bahasa penerima terlihat dari pertanyaan angket nomor $6,7,3$, 13, 14, 9, dan 10, sehingga dapat dirata-ratakan ada 67,06\% siswa yang masih tipis kesetiaannya dalam menggunakan bahasa Indonesia.

c. Terbawanya kebiasaan dalam bahasa Ibu.

Terbawanya kebiasaan dalam bahasa Ibu terlihat dari pertanyaan angket nomor 2, 4, 5, 8, 9, 10, dan 11, sehingga dapat dirata-ratakan ada sebanyak $65,87 \%$ siswa terbiasa menggunakan bahasa ibu (daerah). 


\subsection{Pembahasan}

\subsubsection{Interferensi Gramatikal}

1) Afiksasi

Proses pembentukan kata pada bagian afiksasi ini, yang terdapat dalam teks biografi siswa meliputi prefiks ber-, prefiks me-, prefiks pe-, sufiks -an + sufiks -nya, konfiks $d i-i$, konfiks $k e-a n+$ sufiks $-n y a$, konfiks pe-an, konfiks $k e-a n$, klofiks $m e-i$, dan klofiks $d i-k a n$. Adapun bentuk-bentuk afiksasi tersebut lebih rinci dapat dilihat pada tabel berikut.

Tabel 1. Interferensi Afiksasi

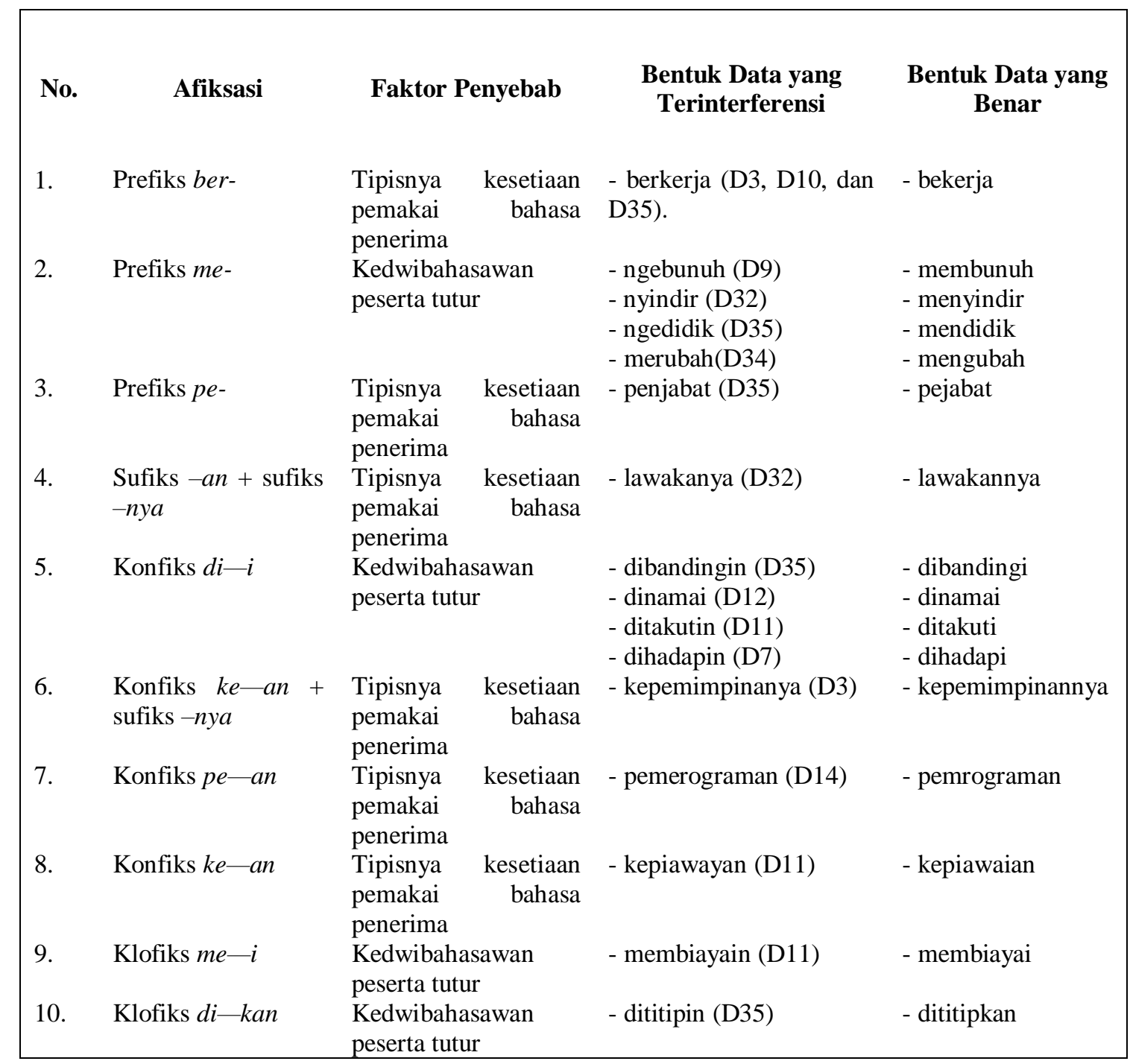

2) Reduplikasi

Proses pembentukan kata pada bagian reduplikasi tidak ditemukan dalam teks biografi siswa. 


\section{JURNAL ILMIAH \\ BINA EDUKASI \\ ISSN 1979-8598 E-ISSN: 2655-8378 \\ http://journal.binadarma.ac.id/index.php/jurnalbinaedukasi \\ Vol. 12, No. 1, Juni 2019, 57 - 71}

\section{3) Komposisi}

Proses pembentukan kata pada bagian komposisi, tidak ditemukan dalam teks biografi siswa.

\subsubsection{Deskripsi Data}

1) Afiksasi (Prefiks ber-)

Pola pembentukan kata dengan prefiks ber- merupakan peristiwa afiksasi yang menyatakan makna "verba". Dalam proses pengimbuhan prefiks ber-dapat terjadi pelepasan fonem /r/ pada prefiks ber- itu, apabila bentuk dasar yang diimbuhi mulai dengan fonem $/ r$ / atau suku pertama bentuk dasarnya berbunyi /er/. Berikut ini wujud interferensi morfologi bahasa Indonesia sebagai akibat penggunaan prefiks ber-. Berkerja (Terdapat pada data 3, data 10 dan data 35). Pada kata Berkerja yang memiliki bentuk dasarnya "kerja" yang suku pertamanya berbunyi /er/ maka, seharusnya ditulis menjadi "bekerja”. Bentukan kata "berkerja” tersebut muncul karena kurangnya kesetiaan siswa (penutur) dalam mempelajari penulisan bahasa Indonesia yang benar.

2) Afiksasi (Prefiks me-)

Pembentukan kata dengan menambahkan afiks nasal pada kata dasar seperti bentukan kata, ngebunuh, nyindir, dan ngedidik, tidak terdapat dalam morfologi bahasa Indonesia.

Proses pengimbuhan dengan prefiks me- dapat berupa pengekalan fonem, penambahan fonem dan peluluhan fonem. Berikut ini wujud bentuk data yang seharusnya diawali prefiks me- bukan prefiks $N$ -

a) Ngebunuh $\longrightarrow$ bunuh $\longrightarrow$ membunuh

Ngebunuh (terdapat pada data 9), bentukan kata tersebutberasal dari kata dasar "bunuh". Dalam proses pengimbuhan dengan prefiks me-, apabila kata dasar diawali dengan konsonan /b/ dan /f/ maka akan terjadi penambahan fonem nasal /m/. Jadi, kata Ngebunuh seharusnya ditulis "Membunuh".

b) Nyindir $\longrightarrow$ sindir $\longrightarrow$ menyindir

Nyindir (terdapat pada data 32), bentukan kata tersebutberasal dari kata dasar "sindir". Dalam proses pengimbuhan dengan prefiks me-, apabila kata dasar dimulai dengan konsonan /s/ maka akan terjadi peluluhan fonem konsonan /s/ menjadi nasal /ny/. Jadi, kata Nyindir seharusnya diberi imbuhan me- menjadi "Menyindir".

c) Ngedidik $\longrightarrow$ didik $\longrightarrow$ mendidik

Ngedidik (terdapat pada data 35), bentukan kata tersebut berasal dari kata dasar "didik". Dalam proses pengimbuhan dengan prefiks $m e-$, apabila kata dasar 


\section{JURNAL ILMIAH \\ BINA EDUKASI \\ ISSN 1979-8598 E-ISSN: 2655-8378 \\ http://journal.binadarma.ac.id/index.php/jurnalbinaedukasi \\ Vol. 12, No. 1, Juni 2019, 57 - 71}

yang dimulai dengan konsonan /d/ maka akan terjadi penambahan fonem nasal /n/. Sedangkan penambahan fonem nasal /-nge/ terjadi apabila bentuk dasarnya hanya terdiri dari satu kata. Jadi, seharusnya bentukan kata ngedidik diberi awalan me- dan ditulis menjadi "mendidik".

d) Merubah $\longrightarrow$ ubah $\longrightarrow$ mengubah

Merubah (terdaoat pada data 34), bentukan kata tersebut berasal dari kata dasar "ubah". Dalam proses pengimbuhan dengan prefiks $m e$-, apabila bentuk dasarnya dimulai dengan konsonan /g, h, kh, a, l, u, e, dan o/ maka akan terjadi penambahan fonem nasal /ng/. Jadi, kata "merubah" yang kata dasarnya diawali konsonan /u/ maka, jika diimbuhi dengan prefiks me-, maka seharusnya ditulis menjadi "Mengubah"

Dapat dipastikan bahwa bentukan kata ngebunuh, nyindir dan ngedidik tersebut, terinterferensi oleh bahasa lisan yang dilakukan oleh penutur (siswa) yang dwibahasawan. Sedangkan bentukan kata merubah tersebut muncul karena kurangnya kesetiaan siswa (penutur) dalam mempelajari penulisan bahasa Indonesia yang benar.

3) Afiksasi (prefiks pe-)

Berikut wujud interferensi morfologi penggunaan prefiks pe-.

Penjabat(Terdapat pada data 35)

Dalam proses pengimbuhan prefiks pe-, akan terjadi penambahan fonem nasal $/ \mathrm{n} /$ apabila bentuk dasar diawali oleh konsonan /d/. Sedangkan pada kata penjabat bentuk dasarnya "jabat" itu artinya tidak diawali konsosan /d/ melainkan konsonan /j/, maka dari itu, pada pengimbuhan prefiks pe- pada kata penjabat tidak ditambahi fonem nasal /n/. Jadi kata penjabat ditulis menjadi "pejabat". Bentuk kata "penjabat" tersebut muncul karena kurangnya kesetiaan siswa (penutur) dalam mempelajari penulisan bahasa Indonesia yang benar.

4) Afiksasi (sufiks -an ) + (sufiks - nya )

Berikut wujud interferensi morfologi dalam penggunaan sufiks -nya.

Lawakanya (terdapat pada data 32). Kata lawakanya terjadi interferensi saat memberi sufiks - nya, pada kata tersebut sufiks - nya berfungsi sebagai pronomina. Tetapi sebelum diberi sufiks -nya, kata lawakanya lebih dulu diberi imbuhan berupa sufiks - an yang berfungsi sebagai nomina. Jadi seharusnya kata lawakanya ditulis dengan dua fonem $/ \mathrm{n} /$, yang mana satu fonem $/ \mathrm{n} /$ untuk memperjelas penggunaan sufiks -an, dan fonem /n/ satu lagi untuk memperjelas penggunaan sufiks - nya. Sehingga ditulis menjadi "lawakannya". 


\section{JURNAL ILMIAH \\ BINA EDUKASI \\ ISSN 1979-8598 E-ISSN: 2655-8378 \\ http://journal.binadarma.ac.id/index.php/jurnalbinaedukasi \\ Vol. 12, No. 1, Juni 2019, 57 - 71}

Bentuk kata "lawakanya" tersebut muncul karena kurangnya kesetiaan siswa (penutur) dalam mempelajari penulisan bahasa Indonesia yang benar.

5) Afiksasi (konfiks di-i)

Berikut wujud interferensi morfologi dalam penggunaan konfiks di-i.

a) Dibadingin (Terdapat pada data 35)

b) Dinamain (Terdapat pada data 12)

c) Ditakutin (Terdapat pada data 11)

d) Dihadapin (Tirdapat pada data 7)

Dalam morfologi bahasa Indonesia tidak terdapat pengimbuhan menggunakan konfiks di-in melainkan pengimbuhan dengan menggunakan konfiks di-i, sehingga dapat dipastikan bahwa bentukan kata dibandingin, dinamain, ditakutin, dan dihadapin tersebut, terinterferensi oleh bahasa lisan yang dilakukan oleh penutur (siswa) yang dwibahasawan. Seharusnya bentukan kata tersebut ditulis dibandingin menjadi "dibandingi”, dinamain menjadi “dinamai”, ditakutin menjadi "ditakuti”, dan dihadapin menjadi "dihadapi".

6) Afiksasi (konfiks ke-an) + (sufiks -nya)

Berikut wujud interferensi morfologi dalam penggunaan (konfiks ke-an) + (sufiks -nya).

Kepemimpinanya (Terdapat pada data 3).Seharusnya kata kepemimpinanya ditulis menjadi "kepemimpinannya" dengan menggunakan dua fonem /n/. Kata dasar “pimpin" + (prefiks pe-) = "pemimpin" + (konfiks ke—an) = "kepemimpinan" + (nya) = "kepemimpinannya".Bentuk kata "kepemimpinannya" tersebut muncul karena kurangnya kesetiaan siswa (penutur) dalam mempelajari penulisan bahasa Indonesia yang benar.

7) Afiksasi (konfiks pe-an)

Konfiks pe-an dalam pembentukan nomina mempunyai enam buah bentuk atau alomorf, yaitu pe-an, pem-an, pen-an, peny-an, peng-an dan penge-an. Bentuk atau alomorf $p e$ - an digunakan apabila bentuk dasarnya berawal dengan fonem /r, l, w, y, m, n, ny dan ng/ sedangkan bentuk atau alomorf pem-an digunakan apabila bentuk dasarnya berawal dengan fonem /b, p, f dan v/. Dengan catatan fonem /b/ tetap diwujudkan, fonem /p/ disenyawakan dengan bunyi sengau dari konfiks yang bersangkutan, sedangkan kata yang berfonem /f dan v/ hingga saat ini masih berupa data potensial. Berikut wujud interferensi morfologi dalam penggunaan konfiks pe-an.

Pemerograman (Terdapat pada data 14). 


\section{JURNAL ILMIAH \\ BINA EDUKASI \\ ISSN 1979-8598 E-ISSN: 2655-8378 \\ http://journal.binadarma.ac.id/index.php/jurnalbinaedukasi \\ Vol. 12, No. 1, Juni 2019, 57 - 71}

Pada bentukan kata di atas seharusnya ditulis "pemrograman" karena, bentuk dasar dari pemrograman adalah "program" yang diawali dengan fonem $/ \mathrm{p} /$, sehingga digunakanlah bentuk pem-an, yang mana fonem /p/ pada kata dasar disenyawakan pada konfiks yang bersangkutan, maka dari itu pemerograman ditulis menjadi "pemrograman". Bentuk kata "pemerograman" tersebut muncul karena kurangnya kesetiaan siswa (penutur) dalam mempelajari penulisan bahasa Indonesia yang benar.

8) Afiksasi (konfiks ke-an)

Berikut wujud interrferensi morfologi dalam penggunaan konfiks ke-an.

Kepiawayan (Terdapat pada data 11). Bentukan kata kepiawayan seharusnya ditulis "kepiawaian", karena kata kepiawaian, memiliki bentuk dasar "piawai" bukan "piaway". Munculnya bunyi semi vocal /y/ diakibatkan karena adanya proses pengimbuhan pada kata dasar "piawai". Tetapi bunyi fonem semi vocal /y/ tersebut tidak perlu ditulis. Sehingga lebih jelas pembentukan kata dasar "piawai" yang diimbuhkan dengan konfiks $k e$ - an, bisa dilihat sebagai berikut.

$($ ke- $)+$ piawai $+(-a n) \longrightarrow$ kepiawaian. Bentuk kata "kepiawayan" tersebut muncul karena kurangnya kesetiaan siswa (penutur) dalam mempelajari penulisan bahasa Indonesia yang benar.

9) Afiksasi (klofiks me-i)

Berikut wujud interferensi morfologi dalam penggunaan klofiks (me-i).

Membiayain (Terdapat pada data 11). Bentukan kata membiayain seharusnya ditulis "membiayai" karena dalam morfologi tidak ada pengimbuhan dengan menggunakan klofiks me-in. Sehingga dapat dipastikan bahwa kata tersebut terinterferensi dari bahasa lisan penutur yang dwibahasawan.

10) Afiksasi (klofiks di-kan)

Berikut wujud inteferensi morfologi dalam penggunaan klofiks di-kan.

Dititipin (Terdapat pada data 35). Proses pengimbuhan tidak ada imbuhan $d i-i$, melainkan konfiks $d i-i$ dan klofiks $d i-k a n$. Klofiks merupakan kelompok afiks yang proses afiksasinya dilakukan bertahap. Seperti pembentukan kata dititipkan, mula-mula pada dasar titip diimbuhkan sufiks -kan setelah itu baru dibubuhkan prefiks di-. Sehingga bentukan kata "dititipin" seharusnya ditulis "dititipkan" karena tidak ada imbuhan $d i-i n$. Bentuk kata "dititipin" tersebut dapat dipastikan karena terinterferensi dari bahasa lisan penutur yang dwibahasawan. 
JURNAL ILMIAH

BINA EDUKASI

ISSN 1979-8598 E-ISSN: 2655-8378

http://journal.binadarma.ac.id/index.php/jurnalbinaedukasi

Vol. 12, No. 1, Juni 2019, 57 - 71

\subsubsection{Faktor-Faktor yang Menyebabkan terjadinya Interferensi}

Berdasarkan hasil angket penelitian terhadap sampel penelitian yaitu sebanyak tiga puluh enam siswa, dapat dilihat persentase faktor-faktor penyebab interferensi dalam tulisan siswa, karena disebabkan oleh faktor berikut.

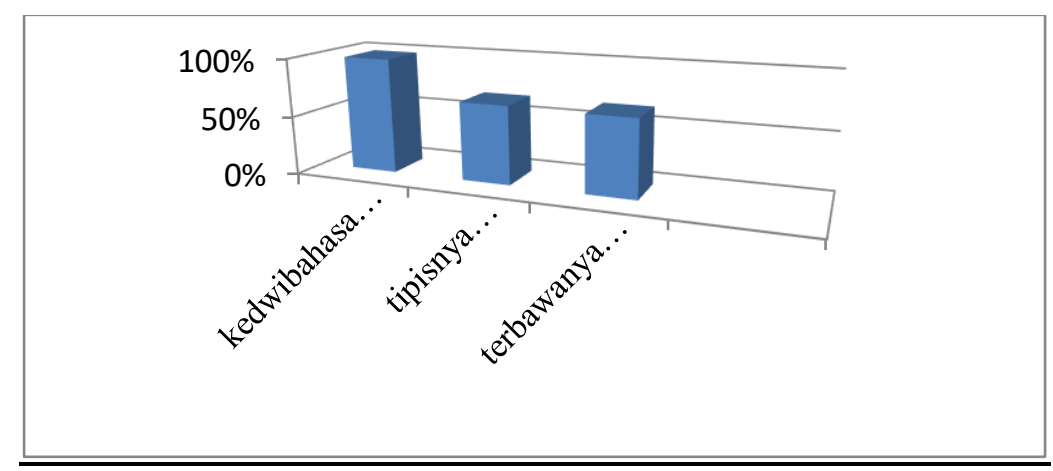

Gambar 1. Faktor Penyebab terjadinya Interferensi

Berdasarkan persentase pada gambar 1 di atas, hasil angket penelitian terhadap tiga puluh enam siswa, dapat dideskripsikan bahwa penyebab terjadinya interferensi pada tulisan siswa karena faktor sebagai berikut.

a. Kedwibahasaan peserta tutur

Berdasarkan soal angket yang berkaitan dengan kedwibahasaan terbukti dengan persentase sebesar 98,61\%, karena dilihat dari jawaban siswa yang mengatakan bahwa mereka menguasai lebih dari dua bahasa dan dalam berkomunikasi seharihari mereka menggunakan dua bahasa secara bergantian dalam situasi dan kondisi tertentu.

b. Terbawanya kebiasaan dalam bahasa ibu

Terbawanya kebiasaan dalam bahasa ibu ini terlihat dari pertanyaan angket yang berkaitan dengan faktor ini, yaitu ada sebanyak $65,87 \%$. Karena hal ini dibuktikan bahwa siswa memiliki kebiasaan memasukkan kata asing atau kata daerah ketika berkomunikasi menggunakan bahasa Indonesia, siswa juga terbiasa menggunakan bahasa daerah tidak hanya di lingkungan tempat tinggal, tetapi pada situasi formal seperti di sekolah siswa tetap menggunakan bahasa daerah, padahal lingkungan formal seharusnya menggunakan bahasa Indonesia, terlebih lagi saat proses pembelajaran berlangsung di kelas siswa tetap menggunakan bahasa daerah dalam mengajukan pertanyaan kepada guru. 


\section{JURNAL ILMIAH}

BINA EDUKASI

ISSN 1979-8598 E-ISSN: 2655-8378

http://journal.binadarma.ac.id/index.php/jurnalbinaedukasi

Vol. 12, No. 1, Juni 2019, 57 - 71

c. Rendahnya kesetiaan pemakai bahasa penerima

Faktor ini terlihat dari angket yang berkaitan tentang kesetiaan pemakai bahasa penerima yaitu sebanyak 67,06\%.Faktor ini terlihat dengan adanya siswa lebih suka dan sering menggunakan bahasa daerah daripada bahasa Indonesia dalam berkomunikasi, dan terlihat juga bahwa dalam menulis siswa tidak memperhatikan penulisan kata baku dengan begitu siswa ketika diminta menulis dengan menggunakan bahasa Indonesia yang baik dan benar ada beberapa siswa yang mengalami kesulitan, bahkan juga ada siswa yang tidak pernah menggunakan bahasa Indonesia dalam berkomunikasi.

\section{SIMPULAN}

Berdasarkan hasil penelitian dan pembahasan mengenai interferensi gramatikal bahasa Indonesia dalam teks biografi siswa kelas X SMA Negeri 1 Palembang, dapat disimpulkan sebagai berikut.

1. interferensi morfologi bahasa Indonesia dalam teks biografi siswa terdapat hanya pada proses afiksasi, sementara untuk proses reduplikasi dan komposisi tidak ditemukan dalam teks biografi yang ditulis siswa,adapun bentuk-bentuk afiksasi yang mengalami interferensi adalah prefiks ber- yaitu pada kata "berkerja", prefiks me-yaitu pada kata "ngebunuh, nyindir, ngedidik, dan merubah", prefiks pe- yaitu pada kata "penjabat", sufiks -an + sufiks - nya yaitu pada kata "lawakanya", konfiks di-i yaitu pada kata "dibandingin, dinamain, ditakutin, dan dihadapin", konfiks ke-an + sufiks -nya yaitu pada kata "kepemimpinanya”, konfiks pe-an yaitu pada kata "pemerograman, konfiks ke-an yaitu pada kata "kepiawayan", klofiks me-i yaitu pada kata "membiayain”, dan klofiks di-kan yaitu pada kata "dititipin";

2. berdasarkan angket penelitian dapat disimpulkan bahwa faktor-faktor yang menyebabkan tejadinya interferensi dalam teks biografi siswa ada tiga faktor, yaitu kedwibahasawan peserta tutur, tipisnya kesetiaan pemakai bahasa penerima, dan terbawanya kebiasaan dalam bahasa Ibu. 


\section{JURNAL ILMIAH}

BINA EDUKASI

ISSN 1979-8598 E-ISSN: 2655-8378

http://journal.binadarma.ac.id/index.php/jurnalbinaedukasi

Vol. 12, No. 1, Juni 2019, 57 - 71

\section{DAFTAR PUSTAKA}

Arikunto, Suharsimi. 2015. Prosedur Penelitian: Suatu Pendekatan Praktik. Jakarta: Rineka Cipta.

Aslinda, dan Leni Syafyahya. 2014. Pengantar Sosiolinguistik. Bandung: PT Refika Aditama.

Chaer, Abdul dan Leonie Agustina. 2010. Sosiolinguistik: Perkenalan awal. Jakarta: Rineka Cipta.

Mahsun. 2006. Metode Penelitian Bahasa: Tahapan strategi, Metode, dan Tekniknya. Jakarta: PT RajaGrafindo Persada.

Mulya, Septi Vina. 2017. Pembelajaran Menulis Teks Biografi Siswa Kelas VIII SMP Global Madani Bandar Lampung Tahun Pelajaran 2016/2017. Skripsi tidak diterbitkan.Bandar Lampung: Fakultas Keguruan dan Ilmu Pendidikan Universitas Lampung.

Putri, Yuka Wirasa. 2014. Interferensi Leksikal Bahasa Indonesia dalam Bahasa Jawa pada Karangan Narasi Siswa Kelas VII SMP Negeri 1 Bukateja di Kabupaten Purbalingga.Skripsi tidak diterbitkan. Yogyakarta: Fakultas Bahasa dan Seni Universitas Negeri Yogyakarta.

Suandi, I Nengah. 2014. Sosiolinguistik. Yogyakarta: Graha Ilmu.

Sugiyono. 2017. Metode Penelitian Pendidikan: Pendekatan Kuantitatif, Kualitataif, dan R\&D. Bandung: Alfabeta.

Sukardi. 2014. Metode Penelitian Pendidikan. Jakarta: Bumi Aksara. 